\title{
Perseverance in Hebrews ${ }^{1}$
}

D Kim (UP)

\section{ABSTRACT}

\section{Perseverance in Hebrews 10:32-13:17}

It is wrong to limit the call to perseverance in Hebrews to chapters 10:3239 and 12:1-13. The whole of Hebrews deals with this theme, but especially 10:32-13:17. This paper focuses on this last section and deals with each semantic unit successively, pointing out not only the prominence of the theme of perseverance throughout, but also the foundation and means of and the different forms of motivation for endurance.

\section{THEME OF PERSEVERANCE IN HEBREWS 10:32-13:172}

1.1 The whole of Hebrews deals with the theme of perseverance, but this theme culminates in Hebrews 10:32-13:17, which forms a structural unit bonded together by the appeal to the readers to remain steadfast in the face of adversity. The different semantic units will be discussed successively.

\subsection{Hebrews 10:32-39}

10:32-39 forms an integral part of 10:32-12:13, which focuses on the themes of "perseverance" and "faith" 3 . Especially, in 10:32-39 the readers are reminded of their former perseverance, which the author wants to serve as a motivation for the readers' present perseverance.

Another motivation for perseverance is the great "reward" (misthapodosia) ${ }^{4}$ which is eschatological. In 10:36 this reward is called the promise, which is also eschatological (that is, the promise will receive its fulfillment only at the consummation). Even if the new covenant people have the assurance that this promise would surely be fulfilled on the basis of Christ's work and therefore have confidence, the promise is still the promise, whose fulfillment lies in the future, and consequently it is necessary to hold on to their confidence and persevere.

Both exhortations in 10:35-36 are supported by the scriptural citations from Isaiah and Habakkuk in 10:37-38. The readers are encouraged to persevere because Scripture says that the period of 
perseverance would not be long and that the only alternative (shrinking back) would cause the destruction of the awaited eschatological life. If you want that life, the only way to receive it is to persevere by doing the will of God. Therefore, the author reintroduces the theme of faith (introduced in $3: 1-4: 13 ; 6: 1-12 ; 10: 22-23)$, which is the foundation as well as the means of perseverances. By persevering through faith we will receive the promise.

By the citation from Isaiah 26:20 our author wants to create the impression that the end time is near and at the same time the period of perseverance is not yet over. But the major Old Testament citation comes from Habakkuk 2:3-4. This citation is very important, because it sets the tone of the argument in 10:32-13:17. (specifically, a note of exhortation to faithfulness and perseverance).

In this respect the paraenetic use of Habakkuk $2: 3-4$ in Hebrews is remarkably different from the polemical use of it by Paul in Romans 1:17 and Galatians 3:11. "Faith" (pistis) is not presented as the means to achieve righteousness before God in contrast to doing works ${ }^{6}$. Rather, in our passage pistis is related to doing the will of God until "he who is coming will come" $(10: 37)^{7}$.

On the basis of and by means of pistis, faithfulness or faithful perseverance (cf German Treue) of God's righteous people becomes possible. In that sense the outworking of pistis in real life, which can be called faithfulness, may be implied in the meaning of pisti ${ }^{8}$. This extended meaning of pistis seems well in accord with the context of Habakkuk 2:3-4. By citing this passage the author encourages the readers not to shrink back, but to persevere until Christ comes again.

\subsection{Hebrews 11:1-40}

In Hebrews 11 the author uses the exemplars of faith in the period before Christ's first coming to persuade the readers to imitate the faith of the ancients, which is expressed in many achievements and partial attainment as well as in perseverance through sufferings in the light of future reward.

Hebrews 11 is a unit dealing with the theme of "faith" (pistis), which was introduced by the citation from Habakkuk at 10:37-38 in relation to "perseverance" (hupomone). Both 10:32-39 and 12:1-13 are concerned about hupomone in suffering and are also related to pistis. Chapter 11 serves as a bridge between those two passages through the use of pistis. Therefore, the purpose of chapter 11 may be considered to be in providing "the foundation for this appeal to the church to endure through 
suffering"9. This purpose is achieved by showing that the real secret of perseverance of the Old Testament saints is pistis. Throughout chapter 11 it is repeatedly demonstrated that the foundation and the means of perseverance of those Old Testament exemplars is pistis ${ }^{10}$.

\subsubsection{Hebrews 11:1-2}

11:1 is to be considered not as a definition of pistis, but rather as a characterization of what pistis does or achieves. In other words, it describes the function of faith rather than the nature of faith. Faith makes real and substantiates things hoped for and demonstrates and gives evidence for things unseen. The perception of the future hope as well as the invisible reality which the future hope is based on is made possible by faith, and this perception motivated the ancients to act in obedience to God's will and persevere in trials and sufferings. Faith produces perseverance by making the perception of the future hope and the invisible reality possible.

\subsubsection{Hebrews 11:3-31}

The anaphoric use of pistis at the beginning of the sentences in 11:3-31 emphasizes the decisive role of pistis by which the people of faith must live and act. Therefore in 11:3-31 we find verbs describing the activities done by people of faith because they elaborate and demonstrate "faith in action".

11:8-22 mainly focuses on Abraham. Abraham was enabled to sojourn in the land of promise through faith and patience. The image of sojourning by faith invokes the future expectation of stable existence as an essential element of faith. The expectation by faith of this stable and permanent city, whose "architect and builder is God", enabled Abraham to obey God's calling and persevere while that expectation remains in the future. As Attridge comments, "faith is seen to motivate obedience and endurance" 11 .

Abraham's faith is well demonstrated in his willingness to offer his only son, Isaac, when tested, despite his dilemma between the divine promise and divine command. 11:17 emphasizes that the divine command was followed by unquestioning obedience because Abraham was absolutely sure of the reliability of God's promise. Abraham's obedience "is set forth as an example of faith, faith manifested in action"12.

The motif that life can come from death through faith, which is introduced in 11:11-12, is further developed in 11:17-19, 35 (cf 13:20) and 
comes to its climax in the example of Jesus who endured the cross and sat down at the right hand of the throne of God (12:2-3).

In 11:21 our author focuses on the fact that Jacob was blessing when he was "dying" (apothnéskōn). Faith reaching beyond death"13 is emphasized. This motif runs through the whole chapter, but especially recurs in 11:8-2214 and binds the stories of the patriarchs in 11:8-22 as a unit.

The examples of faith in 11:23-31 are designed to emphasize the fact that faith enables the people of faith to overcome the fear engendered by the threats of their opponents. The result of fearless ${ }^{15}$ faith was the deliverance of God's people from their opponents.

Faith enabled Moses to regard "abuse for the sake of Christ" as greater wealth than the treasures of Egypt. This seemingly strange estimation of Moses was based on his vision of what could not be seen through physical eyes. Through the eyes of faith he was looking ahead to his reward. Our author's paraenetic purpose brings out this theme of "reward" so that the readers may persevere in view of the coming eschatological reward 16 .

Because the ultimate goal, that is called the reward, is still in the future, the life of faith may involve sufferings until that goal is achieved. These sufferings will be further expanded in 11:35b-38. In view of these sufferings, "not to fear" $(11: 23,27$; cf 13:6) becomes an important element in the life of pistis.

11:27b gives the ground for Moses' faith which enabled him to depart from Egypt without fear. It was because by faith he could see the one who is invisible, that is, God. The result of the vision of God is to "persevere" (kartereō) 17 .

\subsubsection{Hebrews 11:32-38}

The turning point to sufferings with no apparent achievement is reached at $11: 35 b^{18}$. Even though some of the ancients were notable for their deeds and victories, others were not so in the eyes of men. It seemed that these others simply suffered and died, or they at best wandered around while on earth.

These "achievements" through sufferings are dealt with in 11:35b-38 because they seem to reflect the situation of the readers and prepare for the conclusion in 11:39-40 and the transition to 12:1-13. The parallel formula dia [tes] pisteós in 11:33 and 11:39 affirms that those persevering deeds in the midst of sufferings were also achieved through faith. 
$11: 35 \mathrm{~b}$ is a transitional verse which not only points to the next section (11:36-38) by mentioning sufferings and death, but also anticipates the concluding remarks in 11:39-40 by mentioning a "better resurrection" which will only be realized at the time of consummation. The references to "resurrection" and "dead" also recall the incidents related to Abraham $(11: 12,19)$.

\subsubsection{Hebrews 11:39-40}

The author of Hebrews emphasizes the incompleteness of these ancients' achievements. 11:13 and 11:39 make clear that God's wider purpose was not fulfilled under the old dispensation and must be fulfilled in the future. This incompleteness brings "us" onto the scene (11:40) and encourages the readers to endure by faith until they achieve completeness or perfection together with the ancients.

The author tries to persuade his readers to persevere as well as or even better than the ancients by pointing out the fact that God prepared for them "something better" (11:40). This "something better", which was initiated by the first coming of Jesus, has been examined in the central section of the epistle $(4: 14-10: 31)$ and is presented from a different perspective in 12:2-3. The readers have much ampler reason to persevere because they are in a better position than the ancients due to "something better" provided in Jesus Christ.

\subsection{Hebrews 12:1-29}

\subsubsection{Hebrews 12:1-13}

The application to the readers which was prepared in 11:39-40 is achieved in 12:1-3 where Jesus is presented as "the author and perfecter of faith" $(12: 2)$, that is, the climactic example of faith to follow. So faith is still the underlying theme of the new section. In 12:5-11 "der 'Glaube' zeigt sich in der Geduld, im Sichbeugen unter die Züchtigung" 19 .

The distinctive thematic concern for "perseverance" 20 throughout the passage along with its connection to "discipline" 21 and the use of the athletic metaphor in 12:1-3 and 12:12-13 define 12:1-13 as a separate unit.

By beginning the main clause with the phrase di hupomonēs ${ }^{22}$, "the conception of 'patient endurance'... is both syntactically and semantically foregrounded" 23 . This emphasis on hupomone also suggests that the race, which is expressed by the term $a g \delta n^{24}$, is "more marathon than short sprint" 25 . The term agon may have a broader meaning of any "athletic 
contest" or even a broader meaning of any "contest" or "fight". The image of an athletic contest (cf 10:32-33) becomes more specific as a foot-race in our context.

$12: 2$ introduces Jesus, the supreme example or model whom the readers should fix their eyes on, while the reason why Jesus is such an example is given in $12: 2 \mathrm{~b}-3$. The theme of "running the race with perseverance" is highlighted by focusing on Jesus, who is the supreme example of perseverance.

What Jesus has done is exemplary because his life and death demonstrate the typical pattern of the faith-race, consisting of both humiliation and exaltation. "God's election of 'suffering' as an appropriate way to glory is shown nowhere more clearly than in the prototypal life of 'the pioneer'" 26 . The readers are called not only to fix their eyes on Jesus, but also to consider his "perseverance" $(12: 2,3)$ and consequently to follow his example in their response ${ }^{27}$.

In 12:5-11 it is shown that sonship is not incompatible with suffering28; it rather involves suffering as an inherent and necessary part. Here the author wants to strengthen the readers' resolve to persevere in the midst of sufferings and persecutions by viewing their situation from the fresh perspective of paideia. By linking paideia to hupomenõ the author effectively relates 12:1-3 to 12:4-11. Even though 12:4-11 is not based on christology, the word hupomeno invokes the picture of Jesus' perseverance ${ }^{29}$.

Sufferings as "discipline by the loving God" are an indisputable proof of their sonship. As Michel points out, "'Sohnschaft' und 'Züchtigung' werden ... als von Gott gewollter Erziehungsprozeß angesehen" 30 . "Suffering is not in spite of sonship but because of it ... Sonship is ... developed through discipline" 31 . Only those who submit to the discipline and are trained by it will persevere in their race.

The author exhorts the readers to "strengthen your feeble arms and weak knees" (12:12). This exhortation seems to reveal the real situation among the readers: that they are indeed exhausted. The author exhorts the exhausted readers to persevere in their faith-race.

\subsubsection{Hebrews 12:14-29}

It is true that the word hupomone no longer appears from 12:14 onwards, but the appeal for perseverance continues with the emphasis shifted to the cultic and communal aspect of perseverance.

The holiness motif of $12: 10$ is taken up by the repetition of the similar word in 12:1432, thus binding 12:1-13 and 12:14-29 together. In 
order to have a share in God's holiness, which is the ultimate goal of divine discipline, sanctification must be pursued in the context of the community. And the exhortation to pursue "peace" (eirënë) in 12:14 recalls a characteristic element of the fruit of God's discipline in 12:1133. This fruit of peace must be first realized as peace among all the members of the community.

The whole picture in 12:18-21 is intended to emphasize the distance between God and his people in the old covenant situation. But for the new covenant people, though fear is not totally excluded ${ }^{34}$, the unapproachability of God and the distance between God and his people was removed through the person and work of Christ.

The readers have come to the eschatological reality proleptically in their cult. The whole community have come to God $(12: 23)^{35}$ in worshipping God (cf. 12:28). Dahl rightly comments that "through worship they participate in the heavenly worship of the angels, and perfected saints ... i e proleptically" 36 . This proleptic participation in the life of the city to come is a great motivation to continue their pilgrimage to that city. They should persevere in their pilgrimage to reach the final gathering described in 12:22-24, which they now enjoy only proleptically, at the final consummation.

Even though the element of warning still plays an important role in 12:28-29, the whole passage $12: 14-29$ can be characterized as an encouragement to pursue peace and sanctification (12:14) and worship God acceptably (12:28). These two positive encouragements prepare the major themes of chapter 13. The former is developed in 13:1-6, 12-13,16. The latter is developed in 13:10, 15-16 ${ }^{37}$.

\subsection{Hebrews 13:1-17}

In 13:1-6 general ethical admonitions are given. One of the reasons why the style of 13:1ff seems close to that of the rest of the New Testament is that Hebrews also shares the so-called tension between the "already" and the "not yet". How to walk in their community life during the interim period between Christ's first coming and second coming is one of the main subjects of chapter 13 .

In 13:1-17 the readers are reminded that the ultimate realization is still in the future, as in 10:32-12:13. But in 10:32-12:13 the readers were primarily shown the reasons why they must persevere by faith in their sufferings and persecutions. Now in chapter 13 the primary focus of the author is on how they should persevere in the real life of the community. 
Their perseverance must be expressed by their persistence in being actively engaged in community life and worship and offering sacrifices that piease God (13:15-16) until they reach the city that is to come (13:14).

By specifically mentioning the leaders of the community at both $13: 7$ and 13:17, the author tries to put emphasis on the fact that the cultic aspect (both spiritual and practical) of the community life must be conducted under the leadership of the leaders. Even though the leaders play an important role in directing the community life, the cohesion of the community ultimately depends on Jesus, who remains the same (13:8) and suffered death so that he may sanctify his people through his own blood (13:12).

13:7 shows that the readers must consider the "outcome" of the way of life of their leaders and imitate their faith. Probably "outcome" here refers to "a way of life which, as the first readers well knew, remained faithful to the end" 38 .

Their faithfulness can be traced to their pistis in God and his Son, Jesus Christ, who takes the central position in 13:8-16. Therefore, the seemingly abrupt affirmation in 13:8 may be considered as a transition from 13:7 to the following verses. The unchangeability of Christ (13:8) provides motivation not to be carried away by various and strange teachings (13:9).

In 13:13 the author wants the readers to appropriate the benefits of Christ's sacrifice by going to Jesus outside the camp. Along with similarly ambiguous references such as "diverse and strange teachings", "foods", or "altar", the reference to "the camp" appears to be ambiguous intentionally. "It is likely that the image of the camp is designed to be evocative rather than definitive. What it suggests is the realm of security and traditional holiness, however that is grounded or understood" 39 .

The phrase "outside the camp" certainly evokes the scene of the shameful death of Jesus "outside the gate". As the following phrase "bearing" 40 his "disgrace" 41 indicates, the significance of going outside the camp is to identify with Jesus and bear any shame and reproach involved in following him. Jesus first went out bearing his cross and suffered his death on the cross outside the gate. His followers are to bear their own cross and follow him on the way to the cross.

The readers' privilege is to have a unique Christian altar, that is, the sacrifice of Christ. In 13:13 the readers are reminded that bearing his disgrace is an inseparable part of enjoying the privilege of sharing in this altar.

The exhortation in 13:13 is given a further motivation in 13:14. The reason why the readers must go out even bearing his reproach is because 
"here" they do not have an "enduring city", but they are seeking the "coming city". But by going out to Jesus they seek the city to come on a surer basis not only because they now receive mercy and find grace to help them in the time of need, but also because they already enjoy coming to him proleptically in worship.

Once having come to Jesus, who provides them an altar through the sacrifice of himself, the readers are now urged to offer a sacrifice continually to God through Jesus. The cultic argument continues, but it becomes explicitly metaphorical by calling what the readers are to offer a continual sacrifice of "praise". 13:15 is certainly one specific manifestation of worshipping God acceptably (12:28).

The author immediately adds a very practical exhortation without leaving the readers any excuse to fall short of offering fully pleasing worship to God. He says, "Do not forget to do good and to share with others, for with such sacrifices God is pleased" (13:16). These practical things must not be forgotten because they are inseparable parts of Godpleasing worship ${ }^{42}$.

\section{CONCLUSION}

It has become clear that the whole of Hebrews 10:32-13:17 has one main concern: to motivate, in various ways, the readers to persist in their loyalty to their Christian faith. The foundation and means of endurance are their faith. They are motivated to remain steadfast in various ways: by their own previous perseverance, the great reward promised, scriptural quotations, the Old Testament exemplars of steadfast faith and especially by the example of Jesus Himself. Sufferings should be seen from the perspective of paideia: God uses suffering to educate them as his sons. Their perseverance must be expressed by their persistence in community life and worship and by doing good and sharing with others, thus offering a worship pleasing to God.

\section{NOTES:}

1 This paper is a summarized presentation of the main part of my doctoral dissertation, Perseverance in Hebrews, Faculty of Theology (Section B), University of Pretoria, 1995 with Prof A B du Toit as supervisor.

2 The first part of my dissertation dealt inter alia with the macro structure of Hebrews and the more detailed structuring of Hebrews 10:32-13:25.

3 Note that the terms "faith" (pistis) and "perseverance" (hupomone) are used in both 10:32-39 and 12:1-3.

4 Cf 11:26; also 11:6 using "one who rewards" (misthapodotes). 
This statement will be further explained in the next section.

6 That is why Genesis 15:6, which, for Paul, is the basic text for the doctrine of justification by faith (Rom 4:3,22; Gal 3:6; cf Heb 11:7), is not cited even though many events in Abraham's life are used to illustrate his faith.

7 The concept of pistis in Hebrews is very different from, though not contradictory to, that in Paul's letters. But Gräßer is incorrect when he says concerning pistis in Hebrews that "ein christliches Spezifikum is ihr nicht eigen” (E Gräßer, Der Glaube im Hebräerbrief, Marburg 1965, 45). Not only is pistis in Hebrews intrinsically related to Jesus in 12:2, but it also presupposes the christology which is developed throughout Hebrews. In Hebrews, faithfulness is inconceivable without faith in Christ; cf Johnsson who comments that because the problem of the readers, who are already Christians, "was not so much becoming Christian, but continuing as Christian", faith in Hebrews is related to "a matter of constancy in Christian living" (W G Johnsson, In absolute confidence, Nashville 1979, 139).

8 Pistis may imply steadfastness, but is not identical with steadfastness. Note that faith here is not without christological content. If ho erchomenos is not coming, all our endurance is in vain. He who has come to deal with our sin "will appear a second time, not to bear sin, but to bring salvation to those who are waiting for him" (9:28).

$9 \mathrm{~J}$ W Thompson, The beginning of Christian philosophy: The Epistle to the Hebrews, Washington DC 1982, 69.

$10 \mathrm{Cf}$ Gräßer who lists as synonyms of pistis words such as hupostasis, elengchos, hupomone, hupakoe, elpis, parrësia, misthapodosia, katechein, menein and as its antonyms words like hupostolé, parabasis, apeitheia, parakos, hamartia, apostẽnai, parapiptein, hamartanein. In such a list of so-called synonyms and antonyms of pistis he, compiling, misses the interrelationship among those words (Gräßer, ibid, 20); Faith is not identical with perseverance. Rather faith produces perseverance and perseverance is made possible by faith.

11 H W Attridge, A commentary on the Epistle to the Hebrews, Philadelphia 1989, 322.

12 F F Bruce, The Epistle to the Hebrews (rev ed), Grand Rapids 1990, 302.

13 Cf 11:4,13; also "dying" (teleuton) in 11:22.

14 Cf $11: 12,13,19,21$ and 22.

15 The motif of "not fearing" (11:23) recurs in 11:27.

16 Cf 10:35; also note Jesus who endured the cross for the joy set before him (12:2).

17 This use of kartere fits the paraenetic purpose of the author when he uses the word-group hupomeno/hupomone so emphatically in 10:32-36;12:1, 2, 3, 7 .

18 But the transition is achieved smoothly because $11: 35 \mathrm{a}$ and $11: 35 \mathrm{~b}$ are related to each other through the same motif of death and resurrection.

19 O Michel, Der Brief an die Hebräer, "'Göttingen 1975, 426.

20 Cf hupomone in 12:1; hupomeno in 12:2, 3, 7.

21 Cf paideia in 12:5, 7, 8, 11; paideu in 12:6, 7, 10; paideutes in 12:9.

22 This phrase di hupomones points forward to the endurance of Jesus (hupomeno in 12:2,3) and the following paraenesis in 12:4-11 (hupomeno in 12:7).

23 D A Black, ${ }^{-A}$ note on the structure of Hebrews 12,1-2*, Biblica 68 (1987), 545 . 
24 This word occurs frequently in 4 Maccabees to describe the suffering of martyrs along with the imagery of the stadium (4 Macc 11:20;13:15; 15:29; 16:16; 17:11).

25 Attridge, ibid, 355.

26 G Hughes, Hebrews and hermeneutics, Cambridge 1979, 83-84.

27 The life and death of Jesus, which were characterized by trust in God, reverent submission, and obedience to the will of God, make possible the faith response of the readers. So even if there may not be an expression such as "faith-inJesus" in Hebrews, the concept of faith is christologically developed starting from the faith of Jesus. "We are called not only to believe in the risen Christ but also to believe like the earthly Jesus .... . To find in Jesus the supreme exemplar for the life of faith in no way excludes believing in him as the risen Lord of our lives" (G O'Collins \& D Kendall, "Faith of Jesus", Theological Studies 53 (1992), 423).

28 Cf 2:5-18; 5:8.

29 Cf hupomeno in 12:2, 3.

30 Michel, ibid, 426.

31 Jones, ibid, 391-92.

32 Cf hagiotes in 12:10 and hagiasmos in 12:14.

33 Cf eirene in 7:2;11:31; 13:20.

34 Cf 12:23, 28, 29.

35 In Hebrews proserchomai is always used to describe "coming near to God in worship" (cf 4:16; 7:25; 10:1,22; 11:6).

36 N A Dahl, "A new and living way': The approach to God according to Hebrews 10:19-25", Interpretation 5 (1951), 409.

37 In 13:16 sanctification is related to worship by calling the real outworking of sanctification by good works as "sacrifices" pleasing God.

38 P Ellingworth, Commentary on Hebrews, Grand Rapids 1993, 703.

39 Attridge, ibid, 399.

40 This verb may have a connotation of enduring or persevering in the sense of continually bearing the reproach with patience.

41 Cf 10:33, where the readers are reminded of their perseverance in the face of the former exposure to disgrace; 11:26 and 12:2, where Moses and Jesus showed their faith in despising the disgrace.

42 Now the worship concept becomes broad so as to involve the whole life of the readers, as in Rom 12:1; cf. Verhey's comment: "All of life is worship: 'holy unto the Lord" is written on the common and mundane" (A Verhey, "Hebrews: New covenantal exhortation", in: The great reversal: ethics and the New Testament, Grand Rapids 1984, 132). 